\title{
Penerapan Model Pembelajaran Creative Problem Solving (CPS) untuk Meningkatkan Hasil Belajar Siswa Kelas V/A di SDN Ambulu 01 Kabupaten Jember Tahun Pelajaran 2019/2020
}

\author{
Diterima: \\ 3 Januari 2021 \\ Revisi: \\ 25 Januari 2021 \\ Terbit: \\ 1 Februari 2021
}

\author{
Eka Andriani \\ SDN Ambulu 01 \\ Kabupaten Jember, Indonesia \\ E-mail: ekaa1901@gmail.com
}

\begin{abstract}
Abstrak - Pembelajaran berkualitas merupakan proses belajar yang melibatkan siswa secara aktif dan kreatif, sehingga dapat tercipta suasana belajar lebih bersemangat dan menyenangkan. Guru dituntut untuk merencanakan suatu strategi pembelajaran yang efektif dan efiisen. Tujuan dari penelitian ini adalah mendeskripsikan pelaksanaan pembelajaran melalui model kooperatif tipe Creative Problem Solving (CPS) dalam upaya meningkatkan hasil belajar siswa kelas V/A pada materi jaring-jaring kubus dan balok di SD Negeri Ambulu 01 Kabupaten Jember Tahun Pelajaran 2019/2020. Metode yang digunakan dalam penelitian ini adalah penelitian tindakan yang terdiri dari 2 siklus. Masing-masing siklus terdiri dari empat tahapan yaitu rencana tindakan, pelaksanaan, observasi, dan refleksi. Berdasarkan data observasi diperoleh hasil peningkatan hasil belajar pada siswa kelas V/A SD Negeri Ambulu 01 Kabupaten Jember Tahun Pelajaran 2019/2020 melalui penerapan pembelajaran kooperatif tipe Creative Problrm Solving (CPS) pada materi jaring-jaring kubus dan balok. Hasil belajar siswa pada pra siklus sebesar 59,78, pada siklus I sebesar 62,17. Sedangkan pada siklus II sebesar 85,65.
\end{abstract}

Kata Kunci - model pembelajaran, Creative Problem Solving (CPS), hasil belajar

Abstract - Quality learning is a learning process that involves students actively and creatively, so that a more enthusiastic and fun learning atmosphere can be created. Teachers are required to plan an effective and efficient learning strategy. The purpose of this study is to describe the implementation of learning through the Creative Problem Solving (CPS) type cooperative model in an effort to improve the learning outcomes of class V/A students on cube and block nets material at Ambulu 01 Elementary School, Jember Regency in the 2019/2020 academic year. The method used in this research is action research which consists of 2 cycles. Each cycle consists of four stages, namely action plan, implementation, observation, and reflection. Based on observational data, it was found that the results of improving learning outcomes in grade 5/A SD Negeri Ambulu 01 Jember Regency for the 2019/2020 academic year through the application of Creative Problem Solving (CPS) type cooperative learning on cube and block nets. Student learning outcomes in the pre-cycle of 59.78, in the first cycle of 62.17. While in the second cycle of 85.65 .

Keywords - learning model, Creative Problem Solving (CPS), learning outcomes 
ISSN: 2747-1977 (Print) / 2747-1969 (Online)

DOI: https://doi.org/10.53624/ptk.v2i1.46

\section{PENDAHULUAN}

Pelajaran Matematika saat ini tidak lagi mengutamakan pada penyerapan melalui pencapaian informasi, tetapi lebih mengutamakan pada pengembangan kemampuan dan pemrosesan informasi. Untuk itu aktivitas peserta didik perlu ditingkatkan melalui latihan-latihan atau tugas matematika dengan bekerja kelompok kecil dan menjelaskan ide-ide kepada orang lain (Suyadi 2012). Langkah-langkah tersebut memerlukan partisipasi aktif dari siswa, untuk itu perlu ada model pembelajaran yang melibatkan siswa secara langsung dalam pembelajaran. Adapun model yang dimaksud adalah model pembelajaran kooperatif. Pembelajaran kooperatif adalah suatu pengajaran yang melibatkan siswa bekerja dalam kelompok-kelompok untuk menetapkan tujuan bersama. Pembelajaran kooperatif lebih menekankan interaksi antar siswa (Jarmita 2012). Dari sini siswa akan melakukan komunikasi aktif dengan sesama temannya. Dengan komunikasi tersebut diharapkan siswa dapat menguasai materi pelajaran dengan mudah karena "siswa lebih mudah memahami penjelasan dari kawannya dibanding penjelasan dari guru karena taraf pengetahuan serta pemikiran mereka lebih sejalan dan sepadan".

Model pembelajaran kooperatif dapat dijadikan satu alternatif untuk mengatasi rendahnya minat dan motivasi siswa karena dalam pembelajaran kooperatif, kegiatan pembelajarannya lebih menekankan pada kerjasama peserta didik dalam membangun serta mengembangkan pemahaman dan sikap peserta didik sehingga dapat saling berinteraksi dengan temannya untuk menemukan suatu konsep (Qamaria and others 2020). Kegiatan seperti ini akan dirasakan oleh siswa lebih menyenangkan karena siswa tidak hanya duduk diam mendengarkan penjelasan dari guru yang membosankan tetapi mereka dapat belajar mencari tahu dan menemukan sendiri pengetahuan yang mereka butuhkan bersama teman-temannya.

Dari hasil wawancara dan observasi peneliti dengan guru kelas V/A SD Negeri Ambulu 01 Kabupaten Jember .Tahun Pelajaran 2019/2020, diketahui bahwa terdapat banyak kendala dalam proses belajar mengajar mata pelajaran matematika khususnya mengenai materi jaringjaring kubus dan balok. Hal itu bisa dilihat dari nilai siswa pada mata pelajaran matematika mengenai jaring-jaring kubus dan balok yang belum optimal. Dari KKM yang telah ditetapkan oleh sekolah yaitu 65, hanya sekitar $48 \%$ atau 10 siswa yang mencapai KKM dan sisanya sekitar 52\% atau 13 siswa belum mencapai KKM. Padahal proses belajar mengajar dikatakan berhasil apabila telah mencapai ketuntasan belajar dengan prosentase klasikal 75\% (baik). Rendahnya nilai siswa dalam mata pelajaran matematika khususnya tentang jaring-jaring kubus dan balok tersebut dipengaruhi oleh beberapa hal salah satunya pemilihan model pembelajaran yang kurang sesuai dengan materi yang membuat siswa kesulitan dalam memahami materi 
PTK, Vol.2 No.1 2021

ISSN: 2747-1977 (Print) / 2747-1969 (Online)

DOI: https://doi.org/10.53624/ptk.v2i1.46

khususnya dalam mata pelajaran matematika. Hal tersebut muncul karena siswa belum termotivasi dalam mengikuti kegiatan pembelajaran.

Hasil belajar siswa kelas V/A pada materi jaring-jaring kubus dan balok di SD Negeri Ambulu 01 Kabupaten Jember.Tahun Pelajaran 2019/2020 belum optimal. Hal itu terlihat dari beberapa siswa yang masih belum bisa mengerjakan soal dengan benar. Beberapa temuan saat pembelajaran berlangsung bahwa prestasi belajar siswa khususnya Kelas V/A pada materi pokok jaring-jaring Kubus dan balok di SDN Ambulu 01 ,Kabupaten Jember Tahun Pelajaran 2019/2020 sangat rendah yakni 59,6 (Lima Puluh Sembilan Koma enam). Angka tersebut tentunya masih sangat rendah dari KKM yang telah ditentukan. Siswa cenderung hanya menghafal konsep tanpa disertai pemahaman yang memadai.

Untuk strategi pembelajaran, peneliti bersama guru menggunakan model pembelajaran Kooperatif tipe Creative Problem Solving (CPS) untuk mengatasi masalah yang muncul pada siswa dengan menyajikan pembelajaran matematika khususnya materi jaring-jaring kubus dan balok. Dengan menggunakan pembelajaran Kooperatif tipe Creative Problem Solving (CPS), peneliti berkolaborasi dengan guru bertujuan untuk menarik perhatian siswa pada materi yang akan disampaikan, membantu siswa dalam mempelajari matematika untuk anak kelas V. Berdasarkan paparan tersebut di atas maka peneliti melakukan penelitian dengan judul "Penerapan Model Kooperatif Tipe Creative Problem Solving (CPS)untuk Meningkatkan Hasil Belajar siswa kelas V/A pada materi Jaring-Jaring Kubus dan Balok di SD Negeri Ambulu 01 Kabupaten Jember Tahun Pelajaran 2019/2020.”

\section{METODE}

\section{A. Rancangan Penelitian}

Penelitian ini merupakan penelitian tindakan (action research), sebab penelitian dilakukan untuk memecahkan masalah pembelajaran di kelas. Penelitian ini juga termasuk penelitian deskriptif, sebab menggambarkan bagaimana suatu teknik pembelajaran diterapkan dan bagaimana hasil yang diinginkan dapat dicapai. Penelitian ini mengacu pada perbaikan pembelajaran yang berkesinambungan. Model penelitian tindakan adalah berbentuk spiral. Tahapan penelitian tindakan pada suatu siklus meliputi perencanaan atau pelaksanaan observasi dan refleksi. Siklus ini berlanjut dan akan dihentikan jika sesuai dengan kebutuhan dan dirasa sudah cukup atau memenuhi indikator keberhasilan. Sesuai dengan jenis penelitian yang dipilih, yaitu penelitian tindakan, maka penelitian ini menggunakan model penelitian tindakan dari Kemmis dan Taggart (Arikunto 2007), yaitu berbentuk spiral dari siklus yang satu ke siklus yang berikutnya. Setiap siklus meliputi planning (rencana), action (tindakan), observation (pengamatan), dan reflection (refleksi). 
B. Teknik Pengumpulan Data

1. Teknik tes: Lembar kerja peserta didik (LKPD)

Digunakan untuk mengetahui hasil belajar siswa tentang jaring-jaring kubus dan balok dengan model kooperatif tipe Creative Problem Solving (CPS).

2. Lembar Observasi (pengamatan) Kegiatan Belajar Mengajar

Lembar observasi ini dipergunakan untuk memperoleh data aktivitas guru dan aktivitas siswa dalam proses belajar mengajar. Lembar observasi aktivitas guru dan lembar observasi aktivitas siswa dijelaskan lebih rinci sebagai berikut:

a. Instrumen observasi aktivitas guru

Kegiatan guru saat kegiatan pembelajaran jaring-jaring kubus dan balok dengan menggunakan model kooperatif tipe Creative Problem Solving (CPS) disajikan secara rinci dalam tabel 3.1 di bawah ini:

Tabel 1. Lembar Observasi Aktivitas Guru dalam Pembelajaran jaring-jaring kubus dan balok dengan metode CPS

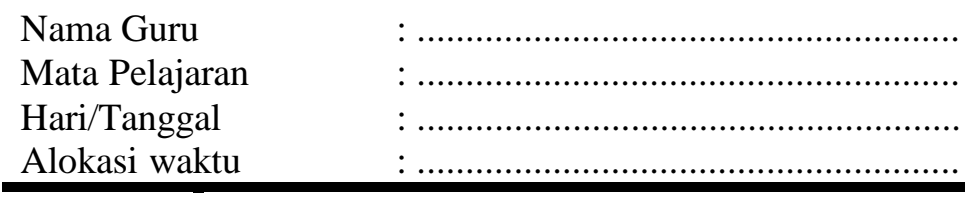

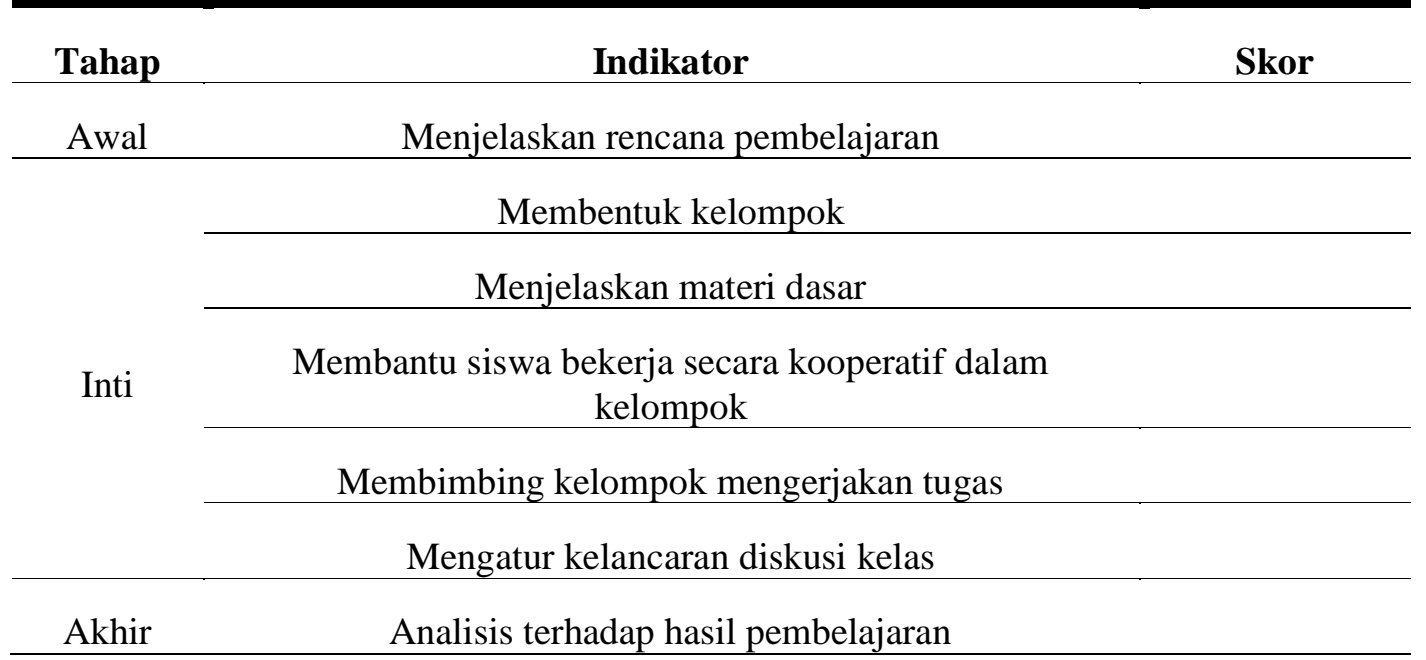

\footnotetext{
Keterangan skor:

$4=$ Baik Sekali

3 = Baik

2 = Cukup Baik

$1=$ Kurang
}

Sedangkan untuk deskriptor dari masing-masing aspek aktivitas siswa di atas, disajikan secara lebih rinci pada lampiran. 
PTK, Vol.2 No.1 2021

ISSN: 2747-1977 (Print) / 2747-1969 (Online)

DOI: https://doi.org/10.53624/ptk.v2i1.46

b. Instrumen observasi aktivitas siswa saat kegiatan pembelajaran

Kegiatan siswa saat pembelajaran Menentukan berbagai jaring-jaring kubus dan balok, tabel 2 di bawah ini:

Tabel 2. Lembar Observasi Aktivitas Siswa Kelas IV dalam Pembelajaran jaring-jaring

kubus dan balok dengan model kooperatif tipe Creative Problem Solving (CPS)

Mata Pelajaran

Materi Pelajaran :

Hari/Tanggal

: $\ldots \ldots \ldots \ldots \ldots \ldots \ldots \ldots \ldots \ldots \ldots \ldots \ldots$

\begin{tabular}{|c|c|c|}
\hline Tahap & Indikator & Skor \\
\hline Awal & Menyimak rencana pembelajaran & \\
\hline \multirow[t]{5}{*}{ Inti } & Duduk secara berkelompok & \\
\hline & Memahami materi dasar & \\
\hline & Keterlibatan menyelesaikan soal dalam kelompok & \\
\hline & Keaktifan diri mengerjakan soal & \\
\hline & Menciptakan kelancaran diskusi kelas & \\
\hline Akhir & Menyimak analisis guru & \\
\hline
\end{tabular}

Keterangan Skor :

4 = Baik Sekali

$3=$ Baik

$2=$ Cukup Baik

$1=$ Kurang

Sedangkan untuk deskriptor dari masing-masing aspek aktivitas siswa di atas, disajikan secara lebih rinci pada tabel 3.4. (lihat lampiran)

c. Instrumen observasi aktivitas siswa dalam diskusi kelompok.

Kegiatan siswa dalam diskusi kelompok disajikan secara rinci dalam penilaian LKS di RPP (terlampir).

\section{Wawancara}

Wawancara adalah percakapan dengan maksud tertentu. Percakapan dilakukan oleh dua pihak, yaitu pewawancara (interviewer) yang mengajukan pertanyaan dan pewawancara (interviewee) yang memberikan jawaban atas pertanyaan itu (Moleong 2007). Peneliti harus mencatat kondisi dan situasi yang mana mendukung penerimaan informasinya yang paling tepat. Sebaiknya pada waktu uji coba, digunakan tape recorder (Arikunto 2007). Teknik wawancara dipergunakan untuk mnengadakan komunikasi dengan pihak-pihak terkait atau subjek penelitian, antara lain kepala sekolah, pembantu kepala sekolah urusan kurikulum, sarana prasarana, guru, 
pengurus komite sekolah, dan siswa dalam rangka memperoleh penjelasan atau informasi tentang hal-hal yang belum tercantum dalam observasi dan dokumentasi.

\section{Dokumentasi}

Analisis dokumen dilakukan untuk mengumpulkan data yang bersumber dari arsip dan dokumen baik yang berada di sekolah ataupun yang berada berada diluar sekolah, yang ada hubungannya dengan penelitian tersebut. Yang termasuk dokumentasi dalam penelitian ini potopoto, hasil wawancara guru dan siswa, dokumentasi ini mempunyai kelebihan, diantaranya yaitu data-data diteliti berulang-ulang untuk lebih menyakinkan dalam membuat kesimpulan.

\section{Teknik Analisis Data}

Dalam rangka menyusun dan mengolah data yang terkumpul sehingga dapat mengahsilkan suatu kesimpulan yang dapat dipertanggungjawabkan, maka digunakan analisis data kuantitatif dan pada metode observasi digunakan data kualitatif. Untuk mengetahui keefektifan suatu metode dalam kegiatan pembelajaran perlu diadakan analisa data. Pada penelitian ini menggunakan teknik analisis deskriptif kualitatif, yaitu suatu metode penelitian yang bersifat menggambarkan kenyataan atau fakta sesuai dengan data yang diperoleh dengan tujuan untuk mengetahui prestasi belajar yang dicapai siswa juga untuk memperoleh respon siswa terhadap kegiatan pembelajaran serta aktivitas siswa selama proses pembelajaran. Untuk menganalisis tingkat keberhasilan atau persentase keberhasilan siswa setelah proses belajar mengajar setiap putarannya dilakukan dengan cara memberikan evaluasi berupa soal tes tertulis pada setiap akhir putaran.

Analisis ini dihitung dengan menggunakan statistik sederhana yaitu.Untuk menilai ulangan atau tes formatif Peneliti menganalisa hasil tes hasil belajar siswa dengan mencari ketuntasan belajar individu Ada dua kategori ketuntasan belajar yaitu secara perorangan dan secara klasikal. Berdasarkan petunjuk pelaksanaan belajar mengajar kurikulum 2006 (Depdikbud 2006), yaitu seorang siswa telah tuntas belajar bila telah mencapai KKM. Adapun KKM telah ditetapkan yaitu sebesar 65. Peneliti melakukan penjumlahan nilai yang diperoleh siswa, yang selanjutnya dibagi dengan jumlah siswa yang ada di kelas tersebut sehingga diperoleh rata-rata tes formatif dapat dirumuskan:

$$
\bar{M}=\frac{\sum X}{\sum N}
$$

Keterangan:

$$
\begin{aligned}
\bar{M} & =\text { Nilai rata-rata } \\
\Sigma \mathrm{X} & =\text { Jumlah semua nilai siswa } \\
\Sigma \mathrm{N} & =\text { Jumlah siswa }
\end{aligned}
$$


PTK, Vol.2 No.1 2021

ISSN: 2747-1977 (Print) / 2747-1969 (Online)

DOI: https://doi.org/10.53624/ptk.v2i1.46

Ada dua kategori ketuntasan belajar yaitu secara perorangan dan secara klasikal. Berdasarkan petunjuk pelaksanaan belajar mengajar kurikulum 2006 (Depdikbud 2006), yaitu seorang siswa telah tuntas belajar bila telah mencapai skor $75 \%$ atau nilai 75 , dan kelas disebut tuntas belajar bila di kelas tersebut terdapat $85 \%$ yang telah mencapai daya serap lebih dari atau sama dengan $75 \%$. Untuk menghitung persentase ketuntasan belajar digunakan rumus sebagai berikut.

$P=\frac{\sum \text { Siswa.yang.tuntas.belajar }}{\sum \text { Siswa }} \times 100 \%$

\section{HASIL DAN PEMBAHASAN}

Dalam pembelajaran siklus I sebagian siswa tidak memperhatikan penjelasan guru, selain itu siswa kurang aktif dalam belajar bersama kelompoknya dan siswa belum dapat menyampaikan pendapatnya pada saat materi pelajaran diajarkan atau pada saat siswa mengalami kesulitan dalam menyelesaikan soal-soal dalam LKPD, hal ini disebabkan karena siswa merasa asing dengan model pembelajaran kooperatif tipe Creative Problem Solving (CPS). Namun pada siklus II, siswa sudah mulai memperhatikan dengan baik penjelasan guru. Selain itu, siswa sudah berani menanyakan hal-hal yang kurang dipahami yang ada kaitannya dengan materi pelajaran yang diajarkan dan mampu mempresentasikan hasil kerja kelompoknya dengan percaya diri.

Siswa terlihat senang mengikuti pembelajaran matematika dengan model pembelajaran kooperatif tipe Creative Problem Solving (CPS), karena menurut mereka dalam pembelajaran kooperatif lebih mudah dalam memecahkan masalah dari tugas yang dikerjakan. Selain itu, dalam pembelajaran kooperatif CPS masing-masing siswa mempunyai tanggung jawabmasingmasing sehingga membuat siswa menjadi lebih aktif.

A. Penerapan Pembelajaran Koperatif Tipe CPS Pada Pokok Bahasan jaring-jaring kubus dan balok

Pembelajaran tentang bangun ruang sisi datar kubus dan balok dengan model pembelajaran kooperatif tipe Creative Problem Solving (CPS) yang dilaksanakan pada penelitian ini dilakukan dengan proses pemahaman siswa sendiri. Dalam hal ini, peneliti sebagai fasilitator dan mediator dan memberikan langkah-langkah pembelajaran kooperatif tipe Creative Problem Solving (CPS). Materi yang diberikan kepada siswa tentang kubus dan balok dalam bentuk Lembar Kerja Siswa (LKS).

Sebelum pelaksanaan pembelajaran, peneliti terlebih dahulu membuat rencana pembelajaran sebagai persiapan mengajar dan mengelompokan siswa secara heterogen dalam kelompokkelompok kecil. Dalam membentuk kelompok jumlah siswa dalam kelas dibagi menjadi 5 
kelompok dengan masing-msaing kelompok terdiri dari 4 dan 5 siswa. Ini sesuai dengan pendapat Slavin (2008), yaitu ukuran kelompok yang sangat ideal adalah 4-5 orang. Kelompok dengan 4-5 orang anggota akan lebih mudah melakukan koordinasi dalam menyatukan ide-ide dan berdiskusi. Masing-masing kelompok diklasifikasikan dengan siswa berkemampuan tinggi, siswa berkemampuan sedang dan siswa berkemampuan rendah.

Pembentukan kelompok-kelompok kecil yang heterogen dimaksudkan untuk membantu siswa dalam memperoleh pemahaman konsep melalui bantuan teman kelompoknya. Interaksi siswa dalam kelompok dapat meningkatkan pemahaman siswa terhadap suatu konsep. Anggota kelompok yang kurang mampu dapat bertanya kepada anggota kelompok yang lebih mampu mengenai hal-hal belum dipahami. Sedangkan siswa yang lebih mampu akan bertambah pemahamannya melalui proses menjelaskan kepada anggota kelompok yang lain atau kepada kelompok lain. Belajar kelompok memberi keuntungan baik kepada siswa kelompok bawah maupun siswa kelompok atas yang bekerja bersama menyelesaikan tugas-tugas akademik.

Untuk menghemat waktu, pembentukan kelompok dilakukan sebelum pembelajaran berlangsung, sebelum pembelajaran, peneliti sudah membagi siswa ke dalam beberapa kelompok sehingga siswa sudah mengetahui kelompoknya masing-masing. Pada saat pembelajaran siswa langsung menempati posisinya masing-masing sesuai dengan kelompoknya. Proses ini sangat menghemat waktu jika dibandingkan dengan pembentukan kelompok pada saat pemebelajaran berlangsung.

Pelaksanaan tindakan dalam penelitian ini meliputi siklus I dan Siklus II. Setiap siklus terdiri dari dua pertemuan. Dan setiap akhir siklus diadakan tes. Tes ini digunakan untuk mengevaluasi pembelajaran dan mengetahui sejauh mana siswa telah memahami materi yang dipelajari. Hasil tes kemudian dianalisis berdasarkan kriteria keberhasilan untuk menetapkan apakah siswa dapat mencapai ketuntas atau belum. Siswa dikatakan tuntas apabila mencapai atau melebihi standar kriteria kriteria keberhsilan yang telah ditetapkan.

Kegiatan pembelajaran pada penlitian ini dilakukan sesuai dengan tahapan dalam pembelajaran kooperatif tipe Creative Problem Solving (CPS) yaitu tahap awal, tahap inti dan tahap akhir dengan langkah-langkah pembelajarannya yaitu:

a. Pendahuluan

1) Guru melakukan apersepsi

2) Guru menjelaskan tentang model pembelajaran CPS

3) Guru menyampaikan tujuan pembelajaran

4) Guru memberikan motivasi

b. Kegiatan inti

1) Tahap pertama 
PTK, Vol.2 No.1 2021

ISSN: 2747-1977 (Print) / 2747-1969 (Online)

DOI: https://doi.org/10.53624/ptk.v2i1.46

a) Penomoran: Guru membagi siswa dalam kelompok yang beranggotakan 5 orang dan kepada setiap anggota diberi nomor 1- 5 .

b) Siswa bergabung dengan anggotanya masing-masing.

2) Tahap kedua

Mengajukan pertanyaan: Guru mengajukan pertanyaan berupa tugas untuk mengerjakan soal-soal di LKPD

3) Tahap ketiga

Berpikir bersama: Siswa berpikir bersama dan menyatukan pendapatnya terhadap jawaban pertanyaan dalam LKPD tersebut dan meyakinkan tiap anggota dalam timnya mengetahui jawaban tersebut.

4) Tahap keempat

a) Menjawab: Guru memanggil siswa dengan nomor tertentu, kemudian siswa yang nomornya sesuai mengacungkan tangannya dan mencoba untuk menjawab pertanyaan atau mempresentasikan hasil diskusi kelompoknya untuk seluruh kelas. Kelompok lain diberi kesempatan untuk berpendapat dan bertanya terhadap hasil diskusi kelompok tersebut.

b) Guru mengamati hasil yang diperoleh masing-masing kelompok dan memberikan semangat bagi kelompok yang belum berhasil dengan baik. Guru memberikan soal latihan sebagai pemantapan terhadap hasil dari pengerjaan LKS.

c. Penutup

1) Siswa bersama guru menyimpulkan materi yang telah diajarkan.

2) Guru memberikan tugas rumah

3) Guru mengingatkan siswa untuk mempelajari kembali materi yang telah diajarkan dan materi selanjutnya.

B. Prestasi Belajar Siswa Setelah Mengikuti Pembelajaran Kooperatif tipe Creative Problem Solving (CPS)

Pada siklus I dan siklus II dari hasil analisis tes menunjukan peningkatan hasil belajar pada bangun ruang sisi datar kubus dan balok setelah menggunakan model pembelajaran kooperatif tipe Creative Problem Solving (CPS). Kondisi ini ditampilkan dalam gambar 1. 


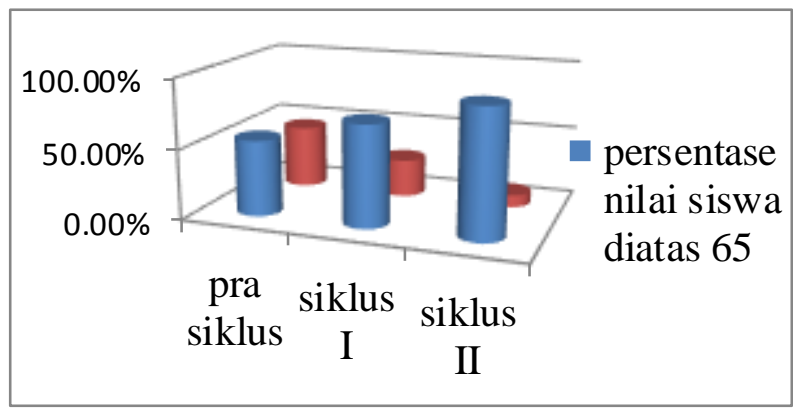

Gambar 1. Presentase Ketuntasan Belajar Siswa Sebelum dan Sesudah Penerapan Metode Creative Problem Solving ( CPS )

Berdasarkan gambar 1 dapat di jelaskan bahwa kriteria keberhasilan yang menyatakan siswa berkategori tuntas belajar minimal $75 \%$ dengan kriteria tuntas belajar apabila nilai hasil evaluasi siswa pada pra siklus, siklus I, II minimal 65. Dari skor dasar tersebut terlihat bahwa ketutntasan belajar siswa $61 \%$, sedangkan siswa yang mendapatkan nilai kurang dari 65 sebanyak 14 siswa. Dengan demikian, persentase siswa yang tidak tuntas adalah 39\%. Hal ini memberikan gambaran bahwa prestasi belajar siswa kelas V/A pada materi Jaring-Jaring Kubus dan Balok di SD Negeri Ambulu 01 Kabupaten Jember Tahun Pelajaran 2019/2020 masih tergolong rendah.

Hasil analisis tes siklus I diketahui bahwa skor persentase siswa yang mendapat nilai 65 lebih banyak dari pada siswa yang mendapat nilai di bawah 65 yaitu persentase siswa yang mendapatkan nilai minimal 65 sebanyak 64\% dan siswa yang mendapat nilai di bawah 65 sebanyak 36\%. Dengan demikian hasil belajar siklus I belum tercapai optimal karena siswa yang tuntas belajar belum mencapai kriteria keberhasilan $75 \%$.

Pada siklus II, skor persentase hasil belajar siswa lebih besar dari pada siklus I. Hal ini diketahui dari peningkatan skor persentase siswa yang mendapat nilai minimal 65 sebanyak 91,7\% dan terjadi penurunan skor persentase siswa yang medapatkan nilai di bawah 65 menjadi 8,3\%. Dari hasil tersebut dapat dikatakan bahwa hasil belajar pada siklus II telah berhasil sesuai dengan kriteria keberhasilan.

Berdasarkan uraian di atas dapat disimpulkan bahwa pembelajaran dengan metode CPS pada pelajaran matematika sangat berpengaruh. Karena pada saat proses pembelajaran siswa sangat membutuhkan suasana yang mendukung demi kelancaran belajar mereka. Dalam hal ini pembelajaran dengan metode CPS sangat berarti bagi siswa ditunjukkan dengan belajar berkelompok dan menunggu giliran yang akan di berikan oleh guru kepada tiap nomor yang ditunjuk. Dengan senangnya siswa belajar sangat berpengaruh atas keberhasilan yang akan di capai pada materi yang disampaikan. 
PTK, Vol.2 No.1 2021

ISSN: 2747-1977 (Print) / 2747-1969 (Online)

DOI: https://doi.org/10.53624/ptk.v2i1.46

C. Respon Siswa Terhadap Model Pembelajaran Kooperatif tipe Creative Problem Solving (CPS)

Respon yang diberikan siswa terhadap model pembelajaran kooperatif tipe Creative Problem Solving (CPS) sangat positif. Hal ini sesuai dengan hasil pengamatan selama pembelajaran, hasil wawancara yang menyatakan bahwa siswa senang terhadap kegiatan pembelajaran kooperatif tipe Creative Problem Solving (CPS), karena lebih percaya diri untuk saling membantu menjelaskan soal-soal matematika kepada teman-temannya. Selain itu, dengan model pembelajaran kooperatif tipe Creative Problem Solving (CPS) siswa menjadi aktif dan mempunyai tanggung jawab terhadap suatu soal matematika untuk dijelaskan kepada temantemannya.

\section{KESIMPULAN}

Pelaksanaan pembelajaran yang dilakukan pada siklus I dan II, dalam pembelajaran matematika pada materi jaring-jaring kubus dan balok dengan menggunakan model pembelajaran kooperatif tipe Creative Problem Solving (CPS) di kelas V/A baik aktivitas guru maupun siswa dalam roses pembelajaran dari siklus ke siklus. Aktivitas guru pada siklus I pertemuan pertama dan kedua yakni $61,1 \%$ dan $91,7 \%$. siklus II pertemuan pertama dan kedua yaitu $96,42 \%$ dan $96,42 \%$. Sedangkan aktivitas siswa siklus I pertemuan pertama dan kedua yaitu $82,14 \%$ dan 89,28\%, siklus II pertemuan pertama dan kedua yaitu 96,42\% dan 96,42\%. menunjukkan adanya peningkatan yang sangat baik. Hasil belajar siswa pada pembelajaran matematika materi jaring-jaring kubus dan balok dengan menggunakan model kooperatif tipe Creative Problem Solving (CPS) dari catatan hasil pembelajaran siklus ke siklus menunjukkan adanya peningkatan hasil pembelajaran pada siklus I dan siklus II menunjukkan perolehan hasil belajar, pemahaman siswa siklus I rata-rata nilainya adalah 62,17\% dan pada siklus II nilai hasil belajar dalam prosentase $85,65 \%$, berarti ada peningkatan $23,48 \%$ ini dicapai karena guru yang optimal dalam proses belajar mengajar, dan semangat siswa yang tinggi.keberhasilan ini ditunjamg dengan adanya keaktivan siswa dalam belajar, dan terjalin kerja sama kelompok yang baik sehingga keberhasilan tercapai. Hasil pembelajaran siswa pun mengalami peningkatan melalui model kooperatif tipe Creative Problem Solving (CPS). 
ISSN: 2747-1977 (Print) / 2747-1969 (Online)

DOI: https://doi.org/10.53624/ptk.v2i1.46

\section{DAFTAR PUSTAKA}

Depdikbud. (2006). Kurikulum Tingkat Satuan Pendidikan Dasar untuk SD Dan MI. Jakarta: Dirjen dikdasmen.

Jarmita, Nida. 2012. "Penerapan Pembelajaran Kooperatif Tipe Stad Dalam Meningkatkan Pemahaman Matematis Siswa Pada Pokok Bahasan Bangun Ruang." JURNAL ILMIAH DIDAKTIKA: Media Ilmiah Pendidikan Dan Pengajaran 13(1).

Moleong, Lexy J. 2007. Metodologi Penelitian Kualitatif. Edisi Revisi. Bandung : PT Remaja Rosdakarya.

Qamaria, Rezki Suci and others. 2020. "The Effectiveness of Google Classroom as English Learning Assistance." Kontribusi: Jurnal Penelitian Dan Pengabdian Kepada Masyarakat 1(1):47-53.

Slavin, Robert E. 2008. Cooperative Learning Teori, Riset dan Praktik. Bandung: Nusa Media

Suyadi, H. M. Suyadi H. M. 2012. "Meningkatkan Prestasi Belajar Matematika Melalui Metode Kooperatif Model Learning Together Pada Siswa Kelas Viif Smp Negeri 21 Semarang Tahun Pelajaran 2011/2012." Media Penelitian Pendidikan: Jurnal Penelitian Dalam Bidang Pendidikan Dan Pengajaran 6(2). 